\title{
Synthesis of 4-Nitro- and 4-Aminophenylazacrown Ethers
}

\author{
Aleksandr S. Oshchepkov, ${ }^{\mathrm{a}, \mathrm{c}}$ Maksim S. Oshchepkov, ${ }^{\mathrm{b}, \mathrm{c}}$ Alexander V. Anisimov, ${ }^{\mathrm{a}}$ \\ and Olga A. Fedorova ${ }^{\mathrm{a}, \mathrm{b}, \mathrm{c} @}$ \\ ${ }^{a}$ Chemistry Department, M.V. Lomonosov Moscow State University, 119992 Moscow, Russia \\ ${ }^{\mathrm{b}}$ D.I. Mendeleev University of Chemical Technology of Russia, 125047 Moscow, Russia \\ ${ }^{\mathrm{c}}$ A.N. Nesmeyanov Institute of Organoelement Compounds of Russian Academy of Sciences, 119991 Moscow, Russia \\ @Corresponding E-mail: fedorova@ineos.ac.ru
}

\begin{abstract}
The study is dedicated to finding optimal reaction conditions for the introduction of 4-nitro- and 4-aminophenyl substituents into the structure of azacrown ethers with a varied ratio of oxygen to nitrogen heteroatoms. The synthetic procedure is proposed for the synthesis of 4-nitroaryl derivatives of crown ethers. This method is remarkably simple, has easy work-up and affords the formation solely of the monoarylation product.
\end{abstract}

Keywords: Crown ethers, heterocyclic derivatives, 1-fluoro-4-nitrobenzene.

\section{Синтез 4-нитро- и 4-аминофенилазакраун-соединений}

\author{
А. С. Ощепков, ${ }^{\mathrm{a}, \mathrm{c}}$ M. С. Ощепков, ${ }^{\mathrm{b}, \mathrm{c}}$ А. В. Анисимов, ${ }^{\mathrm{a}}$ О. А. Федорова ${ }^{\mathrm{a}, \mathrm{b}, \mathrm{c} @}$ \\ ${ }^{a}$ Химический факультет, Московский государственный университет им. М.В. Ломоносова, 119992 Москва, Россия \\ ${ }^{\mathrm{b}}$ Российский химико-технологический университет им. Д.И. Менделеева, 125047 Москва, Россия \\ ${ }^{\mathrm{c}}$ Институт элементоорганических соединений им. А.Н. Несмеянова РАН, 119991 Москва, Россия \\ @E-mail:fedorova@ineos.ac.ru
}

\begin{abstract}
Исследование посвящеено поиску оптимальных условий реакции для введения 4-нитро- и 4-аминофенилзаместителей в структуру азакраун-эфиров с различным соотношением кислородных и азотныхгетероатомов. Предложена методика для синтеза 4-нитроарил-производных краун-эфиров. Этот метод имеет простое лабораторное исполнение. В ходе данной реакиии образуется исключительно продукт моноарилирования.
\end{abstract}

Ключевые слова: Азакраун-эфиры, гетероциклические производные, 1-фтор-4-нитробензол.

\section{Introduction}

Aza-crown compounds have found application in various areas of science and technology: in organic synthesis, in phase-transfer catalysis, in analytical chemistry, in medicine as highly selective ligands for metal cations and as contrast agents for magnet resonance tomography. ${ }^{[1-5]}$ Aza-crown compounds also find use as chemicals for biochemical studies and as building blocks for supramolecular systems. ${ }^{[6-8]}$

Currently there are quite a number of diverse synthetic procedures that lead to aza-macroheterocyclic compounds. ${ }^{[9-14]}$ However, complex functional systems that include azacrown compounds as structural elements have been described to a much lesser extent. The instability of azamacrocyclic compounds under the conditions required to achieve their transformation into complex organic products is one of the reasons for this. Thus, the development of novel pathways to substituted azacrown compounds which could be used as parts in various functional system is an actual synthetic problem. Substituted aryl fragments are usable for such structural modification. The functional groups in the aromatic ring can be used for further modification of the molecule and the aromatic ring itself provides a means to study complex formation processes with optical spectroscopy.

Aryl-substituted azacrown ethers can be synthesized using two basic strategies. The first one involves macrocy- 
clization of linear precursors, one of which bears an aryl group. ${ }^{[15-18]}$ For instance, one of the general methods for the synthesis of $\mathrm{N}$-phenyl azacrown compounds is the basepromoted condensation of $\mathrm{N}$-aryldiethanolamines or their derivatives with oligoethylene glycols and their aza- or thia-analogs. Vogtle and Dix were the first who used such procedure $^{[13,14]}$ to obtain $N$-phenylaza-15(18)-crown-5(6)ethers. When a dichloride is employed as the electrophilic component, the base is usually $\mathrm{NaOH}$, while $\mathrm{NaH}$ is used for ditosylates. ${ }^{[13]}$

The second strategy utilizes direct arylation of azamacrocyclic compounds. ${ }^{[19-21]}$ The advantage of this method is that it allows the use of non-activated and sterically hindered aryl halides. The Buchwald reaction has been the major pathway of such a kind. Palladium-catalyzed reactions, while presenting certain benefits, exhibit a number of disadvantages such as the difficulty of product isolation, moderate selectivity and require comparably complex manipulations. Several examples of the synthesis of $N$-phenylazacrown compounds via arylation of the nitrogen atom are described. ${ }^{[22-25]}$ The halogen derivatives of benzene bearing electron-withdrawing groups are generally employed as the reactants. The reaction conditions (heating of the reactants in a polar or neutral solvent in the presence of a base) depend on the nature of the arylation agent.

The current study describes the reaction conditions for the introduction of a 4-nitrophenyl substituent into the molecules of crown ethers that have different ratios of heteroatoms (oxygen and nitrogen). There are currently two examples of the use of 1-fluoro-4-nitrobenzene for the arylation of aza-crown ethers. ${ }^{[26,27]}$ A single paper presents data on a multi-step synthesis that involves arylation with nitrofluorobenzene resulting in the formation of a monoaryl derivative of cyclen. ${ }^{[26]}$ We have studied arylation of the model compounds (piperidine, morpholine) with nitrofluorobenzene and made an effort to find the optimal conditions for the synthesis of monoaryl derivatives of mono-, di- and tetraazamacroheterocycles. The introduction of a single aryl fragment into the azamacrocyclic molecules allows the further introduction of $N$-functional substituents.

\section{Experimental}

The structure of all obtained compounds was determined by ${ }^{1} \mathrm{H}$ and ${ }^{13} \mathrm{C}$ NMR spectroscopy, mass-spectrometry and further confirmed by elemental analysis. The ${ }^{1} \mathrm{H}$ and ${ }^{13} \mathrm{C}$ NMR spectra were recorded in $\mathrm{CDCl}_{3}$ on a Bruker DRX-400 instrument with an operating frequency of $400.13 \mathrm{MHz}$ using TMS as the internal standard, the measurement accuracy was $0.01 \mathrm{ppm}$ for the chemical shifts and $0.1 \mathrm{~Hz}$ for the coupling constants.

The mass spectra were obtained on an Agilent 1100 Series LC/MSD trap interface operated in positive-ion mode. The analyte solution was injected directly into the device. The flow rate was $400 \mu \mathrm{l} / \mathrm{h}$, the drying gas temperature was $350{ }^{\circ} \mathrm{C}$ and the pressure was 10 psi. The nebulizer needle voltage was $4.5-5.5 \mathrm{kV}$. The isotope distribution was calculated using the Molecular Weight Calculator software, version 6.73.

Cyclam, cyclen, monoaza-18-crown-6-ether, monoaza-15crown-5-ether, diaza-15-crown-5-ether, morpholine, piperidine, $p$-nitrofluorobenzene, potassium carbonate, sodium carbonate, sodium hydroxide, $\mathrm{Ni}-\mathrm{Al}$ alloy $(50 \% \mathrm{Ni} \mathrm{w} / \mathrm{w})$, hydrazine hydrate and solvents (acetonitrile, chloroform, ethanol) were purchased from commercial suppliers (Aldrich, Merck, Ekos-1) and used without further purification.

General procedures for the amination of 1-fluoro-4 nitrobenzene.

$A$. A solution of $p$-nitrofluorobenzene $(0.60 \mathrm{mmol})$ in acetonitrile $(12 \mathrm{ml})$ was added to a solution of $0.80 \mathrm{mmol}$ of piperidine, morpholine or azacrown ether in acetonitrile $(12 \mathrm{ml})$. The reaction mixture was refluxed for $8 \mathrm{~h}$. Then acetonitrile was removed on a rotary evaporator, the residue was washed with water and extracted with chloroform $(3 \times 15 \mathrm{ml})$. The organic layer was separated and evaporated in vacuo. Compounds 1, 2, 6, and 7 were thus obtained as pale yellow powders (see Table 1 for the yields).

$B$. A solution of $p$-nitrofluorobenzene $(0.38 \mathrm{mmol})$ in acetonitrile $(7 \mathrm{ml})$ was added to a stirred solution of $0.38 \mathrm{mmol}$ piperidine, morpholine or aza-crown ether in acetonitrile $(7 \mathrm{ml})$ in the presence of potassium carbonate $(0.4 \mathrm{mmol})$. The reaction mixture was refluxed for $25 \mathrm{~h}$. Acetonitrile was removed on a rotary evaporator, the residue was treated with water and the product was extracted from the aqueous solution with chloroform $(3 \times 15 \mathrm{ml})$. Compounds 1-7 were thus obtained as pale yellow powders (see Table 1 for the yields).

A procedure for the preparation of skeletal nickel catalyst. ${ }^{[14]}$ In a $250 \mathrm{ml}$ beaker slurry $11.0 \mathrm{~g}$ of $\mathrm{Ni}-\mathrm{Al}$ alloy $(50 \% \mathrm{Ni} \mathrm{w} / \mathrm{w})$ was prepared in $110 \mathrm{~mL}$ of water. Solid $\mathrm{KOH}$ was added without any external cooling of the mixture. The addition was carried on until further portions of $\mathrm{KOH}$ caused a visible reaction (about 22-25 g total). When the reaction was settled the mixture was maintained at ambient temperature for $10-15 \mathrm{~min}$ and transferred to a $70^{\circ} \mathrm{C}$ water bath for $30 \mathrm{~min}$. Then water was decanted, and the precipitate was washed thrice with distilled water followed with a triple wash with ethanol. The obtained powder was stored under ethanol.

A general procedure for the reduction of 4-nitro-derivatives of $N$-phenyl azacrown ethers with Raney nickel in ethanolic hydrazine hydrate ${ }^{[14]} 100 \%$ Hydrazine hydrate $(0.7 \mathrm{ml})$ was added to a refluxing solution of nitro-derivative $(1 \mathrm{mmol})$ in ethanol $(6.0 \mathrm{ml})$. Then skeletal nickel catalyst was added until the next successive portion caused a visible reaction. The mixture was maintained at reflux for $1 \mathrm{~h}$, the catalyst was filtered off and the filtrate was evaporated in vacuo (see Table 2 for the yields).

1-(4-Nitrophenyl)piperidine (1), $80 \mathrm{mg}(64 \%$, procedure 1), 56 mg $\left(84 \%\right.$, procedure 2), m.p.: $97^{\circ} \mathrm{C}$ (ethanol) (Lit.: $\left.98-100{ }^{\circ} \mathrm{C}\right) .{ }^{[28]}$

4-(4-Nitrophenyl)morpholine (2), $87 \mathrm{mg}$ (70\%, procedure 1), $70 \mathrm{mg}$ (88\%, procedure 2), m.p.: $161{ }^{\circ} \mathrm{C}$ (ethanol) (Lit.: $157-$ $\left.159{ }^{\circ} \mathrm{C}\right) \cdot{ }^{[29]}$

13-(4-Nitrophenyl)-1,4, 7,10-tetraoxa-13-azacyclopentadecane (3), $67 \mathrm{mg}$ (52\%, procedure 2), m.p.: 126-128 ${ }^{\circ} \mathrm{C}$ (Lit.: $\left.125-127^{\circ} \mathrm{C}\right) .{ }^{[30]}$

16-(4-Nitrophenyl)-1,4,7,10,13-pentaoxa-16-azacyclooctadecane (4), $98 \mathrm{mg}(67 \%$, procedure 2), $93 \mathrm{mg}$ (64\%, procedure 2 with $\mathrm{Na}_{2} \mathrm{CO}_{3}$ as the base), m.p.: $85{ }^{\circ} \mathrm{C}$ (acetonitrile) (Lit.: $\left.83-84^{\circ} \mathrm{C}\right) \cdot{ }^{[27]^{3}}$

7-(4-Nitrophenyl)-1,4,10-trioxa-7,13-diazacyclopentadecane (5), $76 \mathrm{mg}\left(59 \%\right.$, procedure 2), m.p.: $159-161{ }^{\circ} \mathrm{C} .{ }^{1} \mathrm{H} \mathrm{NMR}\left(\mathrm{CDCl}_{3}\right.$, $\left.25^{\circ} \mathrm{C}\right) \delta_{\mathrm{H}}$ ppm: $2.76-2.83\left(\mathrm{~m}, 4 \mathrm{H}, \mathrm{H}_{2} \mathrm{~N}(\mathrm{H})\right) ; 3.57-3.80(\mathrm{~m}, 4 \mathrm{H}$, $\mathrm{CH}_{2} \mathrm{O}$ and $\mathrm{CH}_{2} \mathrm{~N}(\mathrm{R}) ; 6.61(\mathrm{~d}, 2 \mathrm{H}, \mathrm{H}(2,6), J=9.3 \mathrm{~Hz}) ; 8.07$ (d, 2H, $\mathrm{H}(3,5), J=9.3 \mathrm{~Hz}) .{ }^{13} \mathrm{C}$ NMR $\left(\mathrm{CDCl}_{3}, 25{ }^{\circ} \mathrm{C}\right) \delta_{\mathrm{C}} \mathrm{ppm}: 48.3(\mathrm{C}-10)$; 48.5 (C-11); 53.2 (C-7); 53.5 (C-16); 68.3 (C-13); 68.5 (C-15); 70.2 (C-14); 70.31 (C-8); 71.1 (C-12); 76.7 (C-9); 110.6 (C-6); 110.9 (C-2); 126.0 (C-5); 126.2(C-3); 137.2 (C-4); 152.7 (C-1). Mass spectrum (ESI): calculated $m / z=339.4$; found $m / z=340.5[\mathrm{MH}]^{+}$. Found, \%: C, 56.47; H, 7.53. $\mathrm{C}_{16} \mathrm{H}_{25} \mathrm{~N}_{3} \mathrm{O}_{5}$. Calculated, \%: C, 56.62; H, 7.42.

1-(4-Nitrophenyl)-1,4,7,10-tetraazacyclododecane (6). Yield $148 \mathrm{mg}\left(84 \%\right.$, procedure 1), $76 \mathrm{mg}(68 \%$, procedure 2$) .{ }^{1} \mathrm{H}$ NMR $\left(\mathrm{CDCl}_{3}, 25{ }^{\circ} \mathrm{C}\right) \delta_{\mathrm{H}} \mathrm{ppm}: 2.73(\mathrm{~m}, 4 \mathrm{H}, \mathrm{H}(9,12)) ; 2.94(\mathrm{~m}, 4 \mathrm{H}$, $\mathrm{H}(8,13)) ; 3.04$ (m, 4H, H(10,11)); 3.84 (m, 4H, H(7,14)); 6.68 (d, $2 \mathrm{H}, \mathrm{H}(2,6), J=9.3 \mathrm{~Hz}) ; 8.15$ (d, 2H, H(3,5), $J=9.4 \mathrm{~Hz})$. The spectrum corresponds to the literature data. ${ }^{[31]}$ 
1-(4-Nitrophenyl)-1,4,8,11-tetraazacyclotetradecane (7). Yield $156 \mathrm{mg}$ ( $81 \%$, procedure 1), $89 \mathrm{mg}$ (73\%, procedure 2$)$. ${ }^{1} \mathrm{H}$ NMR $\left(\mathrm{CDCl}_{3}, 25^{\circ} \mathrm{C}\right) \delta_{\mathrm{H}} \mathrm{ppm}: 1.90-2.02(\mathrm{~m}, 4 \mathrm{H}, \mathrm{H}(11,16))$; 2.80-2.83 (m, 2H, H(13)); 2.94-2.99 (m, 10H, H(9,10,12,14,15)); 3.58 (m, 2H, H(17)); 3.66 (m, 2H, H(8)); 6.59 (d, 2H, H(2,6), J=9.3 $\mathrm{Hz}) ; 8.10(\mathrm{~d}, 2 \mathrm{H}, \mathrm{H}(3,5), J=9.3 \mathrm{~Hz})$. The spectrum corresponds to the literature data. ${ }^{[26]}$

4-(Piperidin-1-yl)aniline (1a) was obtained according to the general reduction procedure $(162 \mathrm{mg}, 92 \%)$, m.p.: $41^{\circ} \mathrm{C}$ (ethanol) (Lit.: $\left.39-40^{\circ} \mathrm{C}\right) . .^{[28]}$

4-Morpholinylaniline (2a) was obtained according to the general reduction procedure ( $169 \mathrm{mg}, 95 \%)$, m.p.: $131^{\circ} \mathrm{C}$ (ethanol) (Lit.: $\left.128-130^{\circ} \mathrm{C}\right) \cdot{ }^{[28]}$

4-(1,4,7,10-Tetraoxa-13-azacyclopentadecan-13-yl)aniline (3a) was obtained according to the general reduction procedure (270 mg, $87 \%$ ), m.p.: $52-53^{\circ} \mathrm{C}$ (diethyl ether) (Lit.: $\left.51-52^{\circ} \mathrm{C}\right) . .^{[14]}$ 4-(1,4,7,10,13-Pentaoxa-16-azacyclooctadecane-16-yl)aniline (4a) was obtained according to the general reduction procedure (294 mg, $83 \%$ ), m.p.: $37^{\circ} \mathrm{C}$ (acetonitrile) (Lit.: $36-38^{\circ} \mathrm{C}$ ). ${ }^{[32]}$

\section{Results and Discussion}

Amination of $p$-nitrofluorobenzene was conducted in refluxing acetonitrile in the presence of bases - alkaline metal carbonates. Morpholine and piperidine were used as model compounds in order to determine the regularities of the process. Mono-, diazacrown ethers as well as cyclen and cyclam were used as crown ether reactants. The yields of the crowned products corresponding to the use of potassium and sodium carbonate were analyzed to find out whether a template effect takes place. The experimental data are presented in Table 1.

The data in Table 1 demonstrate sufficiently high yields of the products $\mathbf{1 - 7}$, so the employed procedure is suitable for the synthesis of aryl substituted azacrown ethers with a different nitrogen-oxygen ration.

In the case of the model compounds - piperidine $\mathbf{1}$ and morpholine 2, as well as cyclam 6 and cyclen 7, the presence of a base does not have any significant influence on the amination product yield. On the contrary, no amination was observed for the macrocycles bearing both oxygen and nitrogen atoms in the absence of a base. Presumably, the close neighborhood of oxygen atoms diminishes the basicity of the macrocyclic nitrogen to such an extent that amination becomes impossible. When carbonates are added, oxygen-
Table 1. Reaction time and yields for compounds 1-7 for the amination reaction of 1-fluoro-4-nitrobenzene, (acetonitrile, at $\left.78^{\circ} \mathrm{C}\right)$.

\begin{tabular}{cccc}
\hline \multirow{2}{*}{ Product } & \multirow{2}{*}{\begin{tabular}{c} 
Reaction time, \\
\cline { 3 - 4 }
\end{tabular}} & $\mathrm{h}$ & \multicolumn{2}{c}{ Yield, \% } \\
\hline $\mathbf{1}$ & 25 & 64 & $\mathrm{~K}_{2} \mathrm{CO}_{3}$ \\
$\mathbf{2}$ & 25 & 70 & 84 \\
$\mathbf{3}$ & 25 & 0 & 88 \\
$\mathbf{4}$ & 25 & 0 & 52 \\
$\mathbf{5}$ & 25 & 0 & $67^{*}$ \\
$\mathbf{6}$ & 8 & 84 & 59 \\
$\mathbf{7}$ & 8 & 81 & 68 \\
\hline
\end{tabular}

*The yield of 4 in the presence of $\mathrm{Na}_{2} \mathrm{CO}_{3}$ was $93 \mathrm{mg}(64 \%)$.

containing macrocycles can coordinate metal cations, that promotes the dissociation of the salt and activation of carbonate anion as a base.

Another distinctive feature of the studied reaction is monoarylation. Under the described conditions no di- or polysubstitution was observed for diazacrown ether, cyclam and cyclen. A two-fold excess of $p$-nitrofluorobenzene also did not afford diaryl derivatives. Obviously, polyarylation requires more harsh reaction conditions.

At the example of compounds 1-4 it was demonstrated that the nitro-group in the aryl derivatives can be efficiently reduced into an amino group. The presence of a functional amino group gives the possibility of further modification of the compounds in order to obtain various derivatives. Proper reaction conditions for the reduction of compounds $\mathbf{5 , 6}$ have currently not been found by us.

Table 2. Yields of compounds 1a-4a in the reduction of 4-nitroderivatives of $N$-phenylazacrown ethers with Raney nickel in ethanolic hydrazine hydrate solution.

\begin{tabular}{ccc}
\hline Product & Reaction time, $\mathrm{h}$ & Yield, \% \\
\hline 1a & 1 & 92 \\
2a & 1 & 95 \\
3a & 2 & 87 \\
4a & 2 & 83 \\
\hline
\end{tabular}<smiles>[R][C+]=C(C)C(C)=[W]</smiles><smiles>[R]c1ccc([N+](=O)[O-])cc1</smiles><smiles>[R]c1ccc(N)cc1</smiles>

$1-7$ 1a-4a<smiles>[R]=C1CCCCN1C</smiles>
$(1,1 a)$<smiles>CN1CCOCC1</smiles><smiles>CN1CCO[C@H]([18O])COCCOC[GeH2]CC1</smiles><smiles>CC1COCCOCCOCCOCCN(C)OC1</smiles><smiles>C1C[14CH][14CH2]C1</smiles><smiles>CN1CCOCCOCCOCCOCC1</smiles>
(5),<smiles>CN1CCNCCNCCNC1</smiles>
(6),<smiles>CN1CCNCCCNCCNCC1</smiles> 


\section{Conclusion}

The current study presents a simple and efficient procedure for the synthesis of aryl substituted azacrown ethers of different composition. The procedure has simple work-up and affords only monoarylation products. No protective groups are required. Compared to metal-catalyzed amination no expensive catalysts, inert atmosphere and anhydrous conditions are required.

The synthesis of monoarylation products presents the possibility of introduction of other substituents into the structure of azacrown compounds. This allows significant modification of their properties. For instance, additional ligand groups would enhance the complex formation, hydrophobic groups would result in the product being an efficient agent for extraction of metals into an organic phase.

Acknowledgement. The current study was supported by the RFBR grant, project № 15-03-04705.

\section{References}

1. Adachi G.-Y., Hirashima Y. Macrocyclic Complexes of Lanthanide Ions. In: Cation Binding by Macrocycles. Complexation of Cationic Species by Crown Ethers (Inoue Y., Gokel G.W., Eds.), New York: Marcel Dekker, 1990. 701-741.

2. Izatt R.M., Pawlak K., Bradshaw J.S., Bruening R.L. Chem. Rev. 1991, 91, 1721-2085.

3. Yordanov A.T., Roundhill D.M. Coord. Chem. Rev. 1998, 170, 93-124.

4. Gloe K., Graubaum H., Wust M., Rambusch T., Seichter W. Coord. Chem. Rev. 2001, 222, 103-126.

5. Buhlmann P., Pretsch E., Bakker E. Chem. Rev. 1998, 98, 1593-1687.

6. Feiters M.C. In: Comprehensive Supramolecular Chemistry, Vol. 10 (Reinhoudt D.N., Ed.), Oxford: Pergamon Press, 1996. 267-360.

7. de Silva A.P., Gunaratne H.Q.N., Gunnlaugsson T., Huxley A.J.M., McCoy C.P., Rademacher J.T., Rice T.E. Chem. Rev. 1997, 97, 1515-1566.

8. Fedorova O.A., Fedorov Yu.V., Panchenko P.A., Sergeeva A.N., Oshchepkov M.S., Oshchepkov A.S. RU Patent № 2515195, Bull. № 13, p. 2 (in Russ.).
9. Gokel G.W., Korzeniowski S.H. Macrocyclic Polyether Synthesis. Berlin: Springer-Verlag, 1982.410 p.

10. Krakowiak K.E., Bradshaw J.S., Zamecka-Krakowiak D.J. Chem. Rev. 1989, 89, 929-972.

11. Bradshaw J.S., Krakowiak K.E., Izatt R.M. Benzoaza-Crown Macrocycles. In: Chemistry of Heterocyclic Compounds: AzaCrown Macrocycles, Vol. 51, Hoboken: John Wiley \& Sons, Inc., 1993.

12. Elwahy A.H.M. J. Heterocycl. Chem. 2003, 40, 1-23.

13. Dix J.P., Vogtle F. Angew. Chem. 1978, 90, 893-895.

14. Dix J.P., Vogtle F. Chem. Ber. 1980, 113, 457-470.

15. Oshchepkov M.S., Perevalov V.P., Kuzmina L.G., Anisimov A.V., Fedorova O.A. Russ. Chem. Bull., Int. Ed. 2011, 3, 478-485.

16. Fedorova O., Fedorov Y., Oshchepkov M. Electroanalysis 2012, 24, 1739-1744.

17. Fedorova O., Fedorov Y., Oshchepkov M., Dobrovolskaya M. J. Phys. Org. Chem. 2012, 25, 835-839.

18. Fedorov Yu.V., Fedorova O.A., Gromov S.P., Bobrovskii M.B., Andryukhina E.N., Alfimov M.V. Russ. Chem. Bull., Int. Ed. 2002, 51, 789-795.

19. Subat M., Konig B. Synthesis 2001, 1818-1825.

20. Witulski B. Synlett 1999, 1223-1226.

21. Beletskaya I.P., Averin A.D., Bessmertnykh A.G., Denat F., Guilard R. Tetrahedron Lett. 2002, 43, 1193-1196.

22. Leska B., Schroder G., Gierczyk B. ACH-Models in Chem. 1996, 133, 461-462.

23. Gierczyk B., Leska B., Nowak-Wydra B., Schroder G., Wojciechowski G., Bartl F., Brzezinski B. J. Mol. Struct. 2000, 524, 217-225.

24. Collins G.E., Choi L.-S., Callahan J.H. J. Am. Chem. Soc. 1998, 120, 1474-1478.

25. Koike T., Gotoh T., Aoki S., Kimura E., Shiro M. Inorg. Chim. Ada 1998, 270, 424-432.

26. Boiocchi M., Fabbrizzi L., Licchelli M., Sacchi D., Vázquez M., Zampa C. Chem. Commun. 2003, 1812-1813.

27. Jana A., Kumar De A., Nag A., Goswami D., Bharadwaj P.K. Organometall. Chem. 2008, 693, 1186-1194.

28. Saglik B.N., Özkay Y., Özkay Ü.D., Gener H.K. Journal of Chemistry 2014, 2014, Article ID 387309.

29. Arundhathi R., Kumar D.Ch., Sreedhar B. Eur. J. Org. Chem. 2010, 19, 3621-3630.

30. Gromov S.P., Ushakov E.N., Fedorova O.A., Soldatenkova V.A., Alfimov M.V. Izv. Akad Nauk, Ser. Khim. 1997, 6, 1192-1197 (in Russ.).

31. Terreno E., Boniforte P., Botta M., Fedeli F., Milone L., Mortillaro A., Aime S. Eur. J. Inorg. Chem. 2003, 3530-3533.

32. Deveci P., Taner B., Üstündag Z., Özcan E., Solak A.O., Kılıç Z. J. Mol. Struct. 2010, 982, 162-168.

Received 18.02.2015

Accepted 01.05.2015 